\title{
Histological studies on the oesophageal tonsils of broiler ducks
}

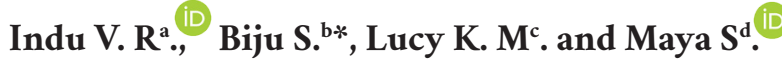

${ }^{a}$ Associate Professor and Head, Department of Veterinary Anatomy \& Histology, College of Veterinary and Animal Sciences, Pookode, Kerala Veterinary and Animal Sciences University, India

${ }^{b}$ Veterinary Officer, Veterinary Quarantine, Ministry of Climate Change and Environment, Hatta Port, Dubai, U.A.E. 'Controller of Examinations and Professor, Department of Veterinary Anatomy \& Histology, Kerala Veterinary and Animal Sciences University, India

dDirector, Academic Staff College and Department of Veterinary Anatomy \& Histology, College of Veterinary and Animal Sciences, Mannuthy, Kerala Veterinary and Animal Sciences University, India
\end{abstract}

Corresponding author: Biju S. | email: drsbiju@gmail.com

Co-authors: IVR: indu@kvasu.ac.in ; LKM: lucy@kvasu.ac.in; MS: maya@kvasu.ac.in

Received: 23-08-2020, Accepted: 29-09-2020, Published online: 06-10-2020

\begin{abstract}
Histomorphological study was conducted on the oesophageal tonsils in six broiler Vigova Super-M ducks of six to eight weeks age. The location of the tonsil was at the junction between oesophagus and proventriculus. In histological sections six to eight isolated tonsillar units were seen in the lamina propria near the base of the oesophageal folds. Each tonsillar unit consisted of a crypt lined by lymphoepithelium and surrounded by dense lymphoid tissue. The tonsillar units were seen encapsulated by connective tissue and composed of many large lymphoid nodules separated by internodular areas. The secretory portion of the mucosal glands of the oesophagus were firmly associated with the lymphoid tissue and the cylindrical epithelium was transformed to lymphoepithelium. The oesophageal tonsils offered immunological protection at the entrance of stomach.
\end{abstract}

Keywords: Oesophageal tonsils, Histomorphology, Ducks

\footnotetext{
doi: https://doi.org/10.51128/jfas.2020.A010 | How to cite this article: Indu V. R., Biju S., Lucy, K.M. and Maya S. 2020. Histological studies on the oesophageal tonsils of broiler ducks. Journal of Food and Animal Sciences, 01(01): 53 - 56.

Copyright: Indu et al. Open Access. This article is distributed under the terms of the Creative Commons Attribution 4.0 International License (http:// creativecommons.org/licenses/by/4.0/), which permits unrestricted use, distribution, and reproduction in any medium, provided you give appropriate credit to the original author(s) and the source, provide a link to the Creative Commons license, and indicate if changes were made. The Creative Commons Public Domain Dedication waiver (http://creativecommons.org/publicdomain/zero/1.0/) applies to the data made available in this article, unless otherwise stated.
} 


\section{Introduction}

In birds, as in mammals, mucosal surfaces are protected by a specialized branch of local immune system called mucosa-associated lymphoid tissue (MALT). The main component of MALT is gutassociated lymphoid tissue (GALT) seen in digestive system of birds due to the absence of lymph nodes and distinct tonsils in oral cavity (Befus et al., 1980). The oesophageal tonsil is a novel member of the mucosalassociated lymphoid tissue (MALT). It is anatomically located cranial to the stomach, unlike the other parts of the GALT (Nagy et al., 2005). Therefore, it is continuously exposed to undigested environmental antigens, allergens, food and infectious agents. Recently researches involving avian GALT are gaining momentum especially in the development of vaccines to be administered orally.

\section{Materials and methods}

For the present study oesophageal tonsils were collected from six broiler Vigova Super-M ducks of six to eight weeks of age. The tonsils collected were cleaned and processed routinely to obtain 5-6 $\mu \mathrm{m}$ thick serial paraffin sections. The sections were stained by Haematoxylin and Eosin (Luna, 1968), Gomori's rapid one step trichrome method for collagen fibres (Luna, 1968), Verhoeff's method for elastic fibres (Singh and Sulochana, 1996), Gordon and Sweet's method for reticular fibres (Bancroft and Gamble, 2003) and Mc Manus's method (PAS) for glycogen (Luna, 1968).

\section{Results and discussion}

The location of the oesophageal tonsil was cranial to the oesophagus-proventriculus junction. It presented six to eight longitudinal folds and thickening in the oesophageal wall as reported earlier by Olah et al., (2003)(Fig. 1). In histological sections in the tonsillar crypts seen in the bottom of the longitudinal folds of oesophagus, lamina propria was heavily infiltrated with lymphoid tissue and formed a tonsillar unit. This was surrounded by a connective tissue capsule (Fig. 2). Here the stratified squamous epithelium (SSE) of oesophagus was converted to lymphoepithelium (LE). In the secretory portion of the oesophageal glands also the epithelium was heavily infiltrated with lymphocytes, macrophages and plasma cells and formed LE. The epithelium lining the excretory duct that opened directly into the lumen of the oesophagus was also infiltrated by migratory lymphoid cells, and transformed to LE (Fig. 3). The oesophageal glands showed strongly positive PAS reaction for glycogen and neutral mucopolysaccharide (Fig.4). The reticular fibres formed an intrinsic meshwork, in which dense distribution of lymphoid tissue was seen (Fig. 5). The lymphoid tissue comprised of small, medium and large lymphocytes, plasma cells and macrophages. The presence of high endothelial venules (HEV) within these regions was suggestive of a close immunological association of the oesophageal tonsil with other lymphoid organs (Nagy et al., 2005). These are in accordance to the reports of Arai et al. (1988). The lymphoid units were seen circumferential in the wall of the esophagus, and did not form a continuous ring. The number of tonsillar units was identical to the number of longitudinal folds, similar to the observations made by Casteleyn et al. (2010). To develop effective oral vaccines, the existence of the oesophageal tonsil has to be taken into account.

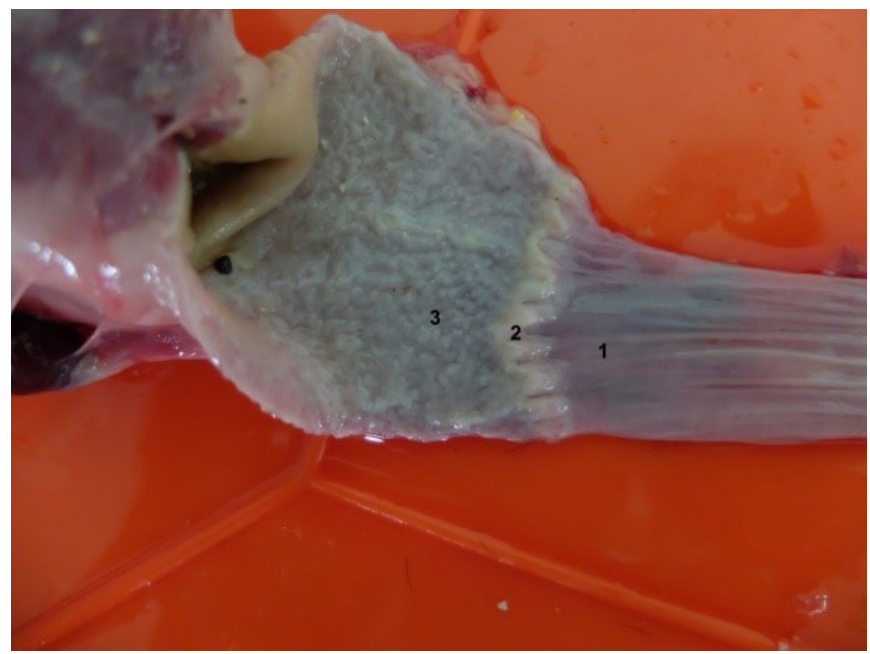

Figure1. Digestive tract of duck

1. Folds in oesophagus; 2.Oesophageal tonsil

3. Proventriculus

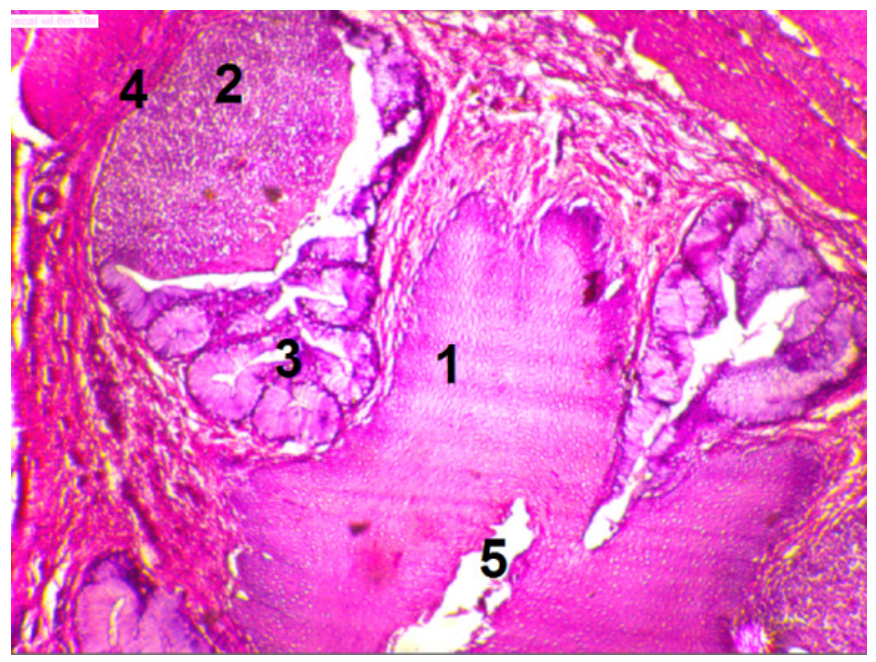

Figure 2. C.S. of oesophageal tonsil showing lamina propria (H\&E X 100)

1. Stratified squamous epithelium

2. Lymphoepithelium

3. Mucous gland with lymphoid accumulation

4. Capsule

5. Crypt 


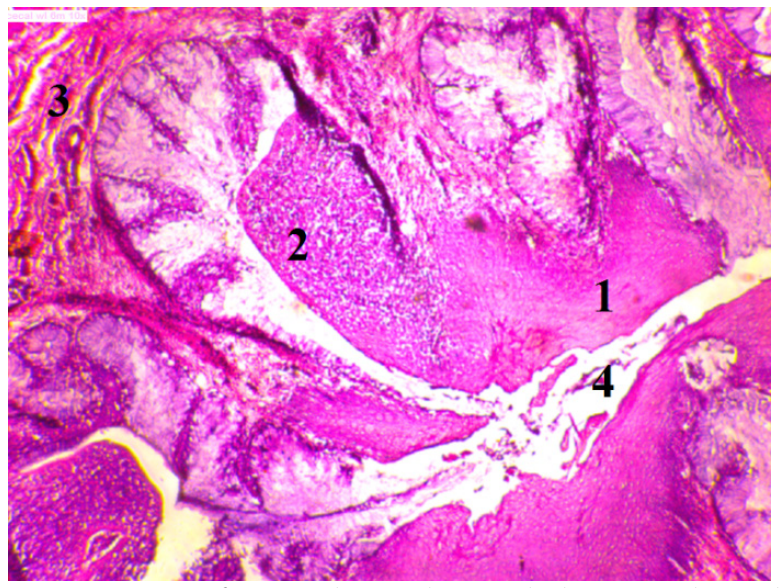

Figure 3. C. S. of oesophageal tonsil showing lymphoepithelium lining the excretory duct (H\&E X 100)

1. Stratified squamous epithelium

2. Lymphoepithelium

3. Capsule

4. Excretory duct

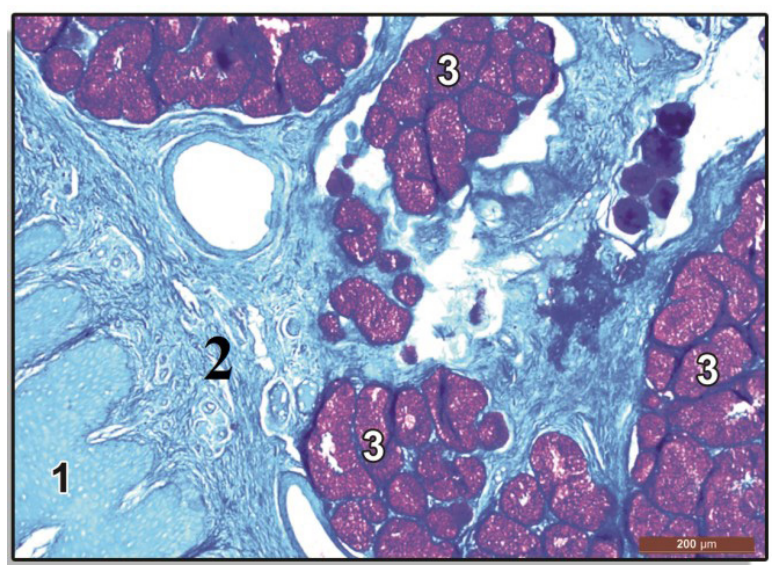

Figure 4. C.S. of oesophageal tonsil showing glands (PAS method X 200)

1. Stratified squamous epithelium

2. Lamina propria with lymphocytes

3. Glands

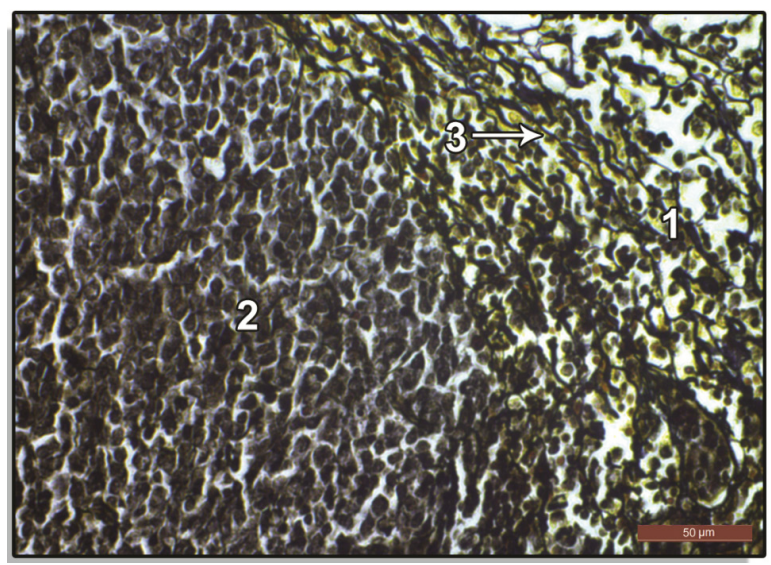

Figure 5. C.S. of oesophageal tonsil showing reticular fibers (Gordon \& sweet silver impregnation method X 400)
1. Cortex;
2. Medulla;
3. Reticular fibers

The avian oesophageal tonsil resembled the palatine tonsils of domestic mammals as observed by Yasuda et al. (2002).

\section{Conclusion}

A study was conducted on the histomorphology of the oesophageal tonsils in six broiler Vigova Super-M ducks. It was observed that the oesophageal tonsils were avian peculiarities and was well developed and seen at the entrance of the stomach and compensated for the absence of palatine tonsils in pharynx. The unique anatomical location might be of major importance for the induction of immunity after per-oral vaccination in birds.

\section{Authorship contribution statement}

Indu V.R.: Conceptualization, Methodology, collection of tissue samples, sectioning, staining, preparation of photomicrograph, Writing - original draft, Writing review \& editing, Project administration.

Biju S.: Conceptualization, Methodology, Writing original draft, Writing - review \& editing, Visualization, Supervision, Funding acquisition

Lucy K.M.: Conceptualization, Methodology, preparation of photomicrograph, Writing - original draft, Writing - review \& editing,

Maya S.: Conceptualization, Methodology, preparation of photomicrograph, Writing - original draft, Writing - review \& editing.

\section{Acknowledgment}

The authors are thankful to the Dean, College of Veterinary and Animal Sciences, Mannuthy and Kerala Veterinary and Animal Sciences University for providing necessary facilities to carry out this work

\section{Funding \\ None.}

\section{Declaration of Competing Interest}

All authors declare that there exist no commercial or financial relationships that could, in any way, lead to a potential conflict of interest.

\section{References}

Arai, N., Hashimoto, Y., Kitagawa, H., Kon, Y. \& Kudo, N. 1988. Immunohistochemical study on the distribution of lymphoid tissues in the upper alimentary and respiratory tracts of chickens. 
Japanese J. Vet. Sci., 50: 183-192.

Bancroft, J.D. and Gamble, M. 2003. Theory and Practice of Histological Techniques. ( $5^{\text {th }}$ Ed.). Churchill Livingstone, New York, 796p.

Befus A.,D., Johnston, N., Leslie G.,A., Bienenstock, J. 1980. Gut-associated lymphoid tissue in the chicken. I. Morphology, ontogeny, and some functional characteristics of Peyer's patches. $J$ Immunol. 125: 2626-32.

Casteleyn, C., Doom , M., Lambrechts, E., Van den Broeck, W., Simoens P. and Cornillie P. 2010. Locations of gut-associated lymphoid tissue in the three-month-old chicken: a review. Avian Path. 39: 143-150

Luna, L.G. 1968. Manual of Histological Staining Methods of the Armed Forces Institute of Pathology. ( $3^{\text {rd }}$ Ed.). Mc Graw-Hill Book Company, New York, 258p.

Nagy, N., Igya'rto', B., Magyar, A., Gazdag, E., Palya, V. \& Ola'h, I. 2005. Oesophageal tonsil of the chicken. Acta Veterinaria Hungarica. 53: 173-188.

Olah, I., Nagy, N., Magyar A. and Palya V. 2003. Oesophageal tonsil: A novel gut-associated lymphoid organ. Poult. Sci. 82:767-770

Singh, U.B. and Sulochana, S. 1996. Handbook of Histological and Histochemical Techniques. Premier Publishing House, Hyderabad, 111p.

Yasuda, M., S. Tanaka, H. Arakawa, Y. Taura, Y. Yokomizo, and S. Ekino. 2002. A comparative study of gut-associated lymphoid tissue in calf and chicken. Anat. Rec. 266:207-217. 